\title{
Writing on The Walls: It Isn't Just Graffiti
}

Charles Huckelbury, Jr.

\section{W} riting is a surreal business under the best of circumstances but even more so for those of us in prison. Solely because of our status, we must overcome disadvantages free writers never face. If we write on an academic level, sharing our insights and experiences, the public assumes we are either whining or trying to advance a self-serving agenda. If we write fiction, we also face a distinctively hostile audience, conditioned to reject anything created in America's prisons while paradoxically celebrating works from men and women jailed overseas by regimes inimical to American interests. In the United States, indigenous convict writers are viewed in the same light as garden slugs encountered on the patio during a dinner party. The first instinct is to get us out of sight and keep us there, as though we have no redeeming value whatsoever. And sadly, some of us have contributed to that reaction.

Jack Abbott was a federal prisoner of some literary talent when he was discovered by Norman Mailer. Abbott eventually published In the Belly of the Beast, a moving collection of essays describing what it means to do hard time. He was lionized by the literati and fêted all over New York. He could have accomplished a great deal as our ambassador, but shortly after Mailer got him out of prison, he killed a waiter in an incredibly stupid altercation over using a bathroom in a Manhattan restaurant. That of course enabled a sceptical and vindictive public to point its collective finger at Abbott and say, "See? We should have left him where he was".

That identical prejudice exists from Maine to California, even without the validating crimes committed by authors given Abbott's kind of squandered opportunity. Granted, only the most morbid minds outside the forensic community would want to read the work of, say, Timothy McVeigh or Ted Bundy, but there are men and women who, like Abbott, write from cells and who do have something significant to say, either in their fiction and poetry or in their essays. Still, the philosophical framework in which their writing takes form clashes with the conventional wisdom, and it is this cognitive dissonance that produces a comprehensive rejection when potential readers learn that the author is a convict. The public immediately leaps up and screams about gratuitous concern for more prison amenities, accusing us of selfishly appropriating emotional capital better invested with their own families. 
Stridency overwhelms logic, leaving us to face journalistic howitzers while armed with pop guns.

In addition to the belligerent emotional reactions to our work, we must also deal with the current legislative trend to deprive us of our intellectual properties. Many states now have laws that rigorously prevent prisoners from profiting by their crimes. These measures can include confiscation of all monies paid as a result of interviews or book or movie contracts that deal specifically with the particular crime that got us our prison sentences. Even I find it hard to argue philosophically against such measures, as restrictive and prejudicial as they appear. I can list dozens of heinous crimes for which compensation to the guilty party would be morally reprehensible, no matter how the book or movie deals might be pitched. If such lucrative contracts resulted, then my first response would be to allow seizure of those assets to be distributed among the victims or their families, which, of course, is the rationale driving all of these measures.

But many of these laws go beyond appropriation of assets derived from a specific crime. More draconian statutes now provide for confiscation of monies gained from the sale of any creative properties. This includes everything from magazine articles to prizes in literary contests to screen plays. Depending on the jurisdiction, no matter what you write, you might be forced to relinquish everything you gain from its sale. Your family, no matter how impoverished, would never see any of it. Most States claim that these assets go toward offsetting the expense of housing the prisoners whose money finds its way into the state's coffers. Whether you can believe legislators and members of Congress regarding fiscal responsibility is a subject for another essay. I think that instead of redistribution of wealth as the primary goal, many people simply do not want to see us rise above our designated station in life. When we do, it compounds the evidence militating against the standard lie that we are worthless. Thus, to eliminate the conflict, the public is swayed into passing laws that deprive of us the fundamental liberty, the freedom to create.

My point is that writing inside prison is often a lonely and discouraging experience if one writes for public approval. The problem unfortunately is that we must if we are to alter the prehistoric attitudes of today's electorate. And who amongst us does not want recognition in its own right, especially after labouring over a piece conceived and 
executed during the quiet hours, at 4:00 in the morning, when nearly everyone but the HBO addicts are asleep? Just a word of acknowledgement, even in opposition, would be nice if only to let us know that someone out there is aware of what we are trying to do. Instead, we typically earn silence or hostility for our efforts.

But that does not mean we roll over and surrender. Although encouragement rarely comes, we are usually too stubborn to surrender, to accept what Blake called the "mind-forged manacles" imposed by those who do not understand and are unwilling to make the effort. We then learn to persist, to write for the sheer love of our craft, for the joy and satisfaction that using the language brings. And that is when our work begins to sing.

This dedication, however, comes with a caveat: we must guard against an unsuspecting participation in our own vilification, not in what we have done but in what we write. When we commit our thoughts to paper, we risk both pain and discovery because our best work always contains a piece of us. We in effect conspire in the condemnation if what we write does not conform to accepted ideology or worse, attacks some social or cultural icon. And, of course, it usually does; those inhabiting society's lowest stratum are always rebellious and often unrepentant.

If we do not, as Pericles urged, meet this danger with a light heart, we consequently become acutely territorial, even aggressive, about our work. We hurl down the gauntlet of righteous indignation and tell the public in no uncertain terms to go directly to hell without passing Go or collecting two hundred dollars. This repudiation of adverse public reaction turns our writing exclusively into a means of self-validation, often a strident one, an expression of the soul that defies attempts to injure or kill us spiritually. In and of itself, this transformation aids in our survival and protects us from those psychological slings and arrows we constantly endure on talk shows and C-SPAN. But to have an impact on local or national policy, we must be prepared to bend in the wind of critical response rather than categorically ignore the reasoned debate of people who disagree with or even despise us.

For prison writers, myopia is more pronounced than in the general population. We tend to reject "outside" criticism as either unfounded or uninformed, believing that anyone who has not done time cannot possibly know what it is like and therefore cannot write competently about it. We believe that only convicts can write about convicts and the 
conditions in which we exist. There is an element of truth in that sentiment, but such parochialism limits us even more. If we write only and about each other, then we maintain the dichotomy that currently insulates us from society and this decreases our prospects for a wider readership, something we clearly need if we are to change the antagonistic dispositions of the people who make the decisions. Even if the free world does not understand what we write or disagrees with it philosophically, we must keep our ideas and creativity fresh and continue to explore avenues for interaction if we are to make inroads against their intrinsic prejudice. That means continued writing in the face of rejection, never forgetting that we are neither the first nor the last to travel this path. Many successful authors can literally wallpaper their homes with rejection slips, and even Jack Kerouac took six long years to find a publisher for his classic On the Road.

In view of the customary response, even without Abbott's selfdestruction, I began writing with no expectations of any approval beyond the classroom. That was challenge enough, because, as all writers know, baring your soul in your work and then offering someone else a scourge with which to beat you is an intimidating experience. As I grew, I learned to accept constructive criticism and to trust my instincts. I also learned to ignore - at least partially - the howls of protest or the venomous silence that greeted my every attempt to go public with my work. I subsequently concentrated on fiction because I believed that no one would want to read academic work from a convict. I thought my opinions would not matter "out there", and the current political climate always reminded me that I was inconsequential, less than a thorn in the lion's paw. My attempts to approach the unfettered world in essays usually did not merit the courtesy of a response, although I always enclosed return postage. It was as if my submissions had disappeared into some literary black hole reserved for the manuscripts of convicts.

Last year, for example, I wrote a descriptive, lyrical piece on the coming of fall in New England and the pageantry displayed when the hardwoods begin to turn. I submitted it to a magazine here in New Hampshire that usually features that kind of an article, but I never got so much as an acknowledgement. The same thing happened with other submissions on other topics to newspapers and magazines. Only The Boston Globe responded when I inquired about being a regular contributor to their Features section: they politely told me no, but at least 
they told me something. In perhaps the grossest insult, a literary agent in Illinois returned a query for a novel unopened because the mail room here had stamped the envelope with the prison's name as the point of origin. He wanted nothing to do with any submission by a convict, regardless that it might cost him money over the long term.

To anticipate such rudeness and overt hostility, I usually ask other prisoners to vet my work. I try to pick men who will be candid about what they read, similar to an editor's function in the real world, and not try to spare my feelings by ignoring a deficiency where it exists. This does not mean I restrict the process to English majors. To the contrary, I seek discrete levels of both education and experience, needing a gutlevel response to what is on the page, especially with my fiction. When I write about "The Life", I strive for accuracy among those men who have walked the walk.

With that in mind, I must rely on others for technical points as well as literary criticism. I have been in prison for 25 consecutive years and obviously have no contemporary experience with ATMs, late-model automobiles, or even something as elementary as shopping. My prose accordingly can suffer from my ignorance. In one of my short stories, for example, a character changed the station on a new Porsche's radio by turning the knob. Then one of my readers reminded me that car radios are now all digitalized. It was a small mistake, but as convict writers, we cannot afford them. We must be absolutely ruthless about our own work or risk providing our most formidable critics ammunition to pick us apart. Yet in a bizarre tautology, often those hardships imposed on us by society provide us with material for what we eventually create. (The richness of the blues would not have seen the light of day had not black men and women suffered and endured.) As with the burdens enslaved peoples must bear as a result of their imprisonment, we also have a wealth of experiences that transcend those of contemporary writers. It is necessary, however, to add perspective to those experiences and to mould them into a story that someone else wants to read.

Even as a young man with less dramatic tales to relate, I had the urge. I longed to be able to write for a wide audience. I wanted to be the one to take readers where I decided they should go, to be a guide to unknown worlds and sensuous experiences beyond their own, because by serving as their guide, I also get to make the trip with them. When I write, I can leave my cell whenever I desire, and I still cheer 
unabashedly as favourite characters succeed and despised ones fail. In my work, if not in the physical world I endure daily, justice does exist and optimism is not a chimera. Effort counts for something, and not all bad guys wear black hats. And it all happens with no inane commercials for rodeo burgers or adult diapers. It does, however, demand both effort and discipline if readers are to respond viscerally to the characters and action the words on the page evoke in their minds.

As odd as it sounds to people who do not write, fiction writers have little control over their own characters, if indeed those characters remain the property of the man or woman who creates them. The characters and the events in which they participate often take on lives of their own, evolving in their peculiar ways and speaking dialogue that the writer should never have guessed would come out of their mouths when $\mathrm{s} / \mathrm{he}$ first sat down to write. Certainly, the writer places people in specific environments and has a rough idea of where the piece should go, but the characters who populate a novel or short story become largely autonomous. It is precisely this sense of freedom that I think most prison fiction writers appreciate and attempt to cultivate in their art.

I exercised that privilege in my first fictional efforts by doing what many of us practice. I created romans à clef, camouflaged autobiographies, as a means of sublimating my anger and frustration, and as a means of living like a normal human being. I got back at certain guards who had shown me more than the average amount of disrespect, or else I spent time with my wife in locations I could visit only in my imagination. Since my writing took me anywhere I wanted to go, I got to choose the time and place and fill the space with characters both good and evil. I could be Everyman or Superman, and I never had to be subservient to an intellectual or physical inferior, piss in a bottle while someone watched, or locked in a cell for count. I could sit in Newton's classroom or watch one of Shakespeare's plays at the Globe. To the uninformed, this sounds like pure escapism, but the therapeutic benefits, if not the financial rewards, have been boundless. And those of us who write from inside know how critical it is to maintain our intellectual and emotional poise.

I remember a specific writing class in which maybe a dozen of us were workshopping our papers, reading them aloud for critical analysis by the other students. Something had happened while I was writing a novella, something that victimized one of the most decent and beautiful 
people I have ever met, a very special woman who had been kind to me when she did not have to be, at a time that became a watershed in my life. I knew who the guilty party was, and I made him the villain in this particular piece. I created a graphic scene in which he was richly rewarded - at least in my view - for his transgressions By objective standards, it was brutal, but in our world of what goes around comes around, it was justice served. At the end of the reading, one of the other students in the hushed classroom turned to me and said softly that I had been in prison too long. I certainly agreed with him, but the catharsis that accompanied writing that piece and then reliving it as I read it for others, doubtless helped me reap psychological benefits that would have otherwise cost me dearly.

These are considerations that free writers never have to entertain. They do not live in an oppressive environment where mental sublimation is the only available remedy to stave off encroaching insanity. Yes, they can imagine themselves in specific situations and then write something to redress it, but we are compelled to live the situations before writing about them, either in fictional or nonfictional accounts. Few of today's authors have ever seen unrestricted violence or sudden death. Fewer still know what it feels like to be hunted, to have no choices in their daily lives, or to be on the wrong end of a gun, whether in the hands of a cop, soldier, or bad guy. Even Thomas Wolfe did not know what it meant never to be able to go home again. This is not to say that experience is a prerequisite for good writing, but writers write best about subjects they know. When we write about a particular event in our lives, whether cloaked in fiction or exposed as the real nitty gritty, the result carries the authority of having been there and done that.

The written word, unlike a passive medium like television, demands participation of both author and reader in a symbiosis not found elsewhere. People read about the characters we create, and their imagination brings them to life. They live lives we describe and vicariously share the actions of everyone else we choose to give them. In other words, we all think while we read (and write) and we get (or give) something in the process, a process that is a relentless quest for improvement. For me, that usually means learning to be coldly objective, specifically, knowing when to cut. As my writing professor once warned me, it can seem like infanticide, killing my own progeny as soon as it saw the light of day. Early on, I was loath to admit that anything I wrote 
was defective. I was as protective as a mother who has given birth to a three-headed jackass. I thought my issue was beautiful and automatically valuable, no matter how ugly it looked to anyone else. It hurt to admit I could compose junk, but it is a realization all writers must face sooner or later. All of us who write have substantial egos, but we must keep them under control if we are to perfect our work and deal with the inevitable disappointment when we are not up to the task. Yes, I said inevitable.

No matter how one approaches writing or the particular venue, do not be surprised on the days when your conceptual powers allow you to write incessantly - or especially! - on the days when nobody is home up there. The creative process is always a mysterious one, and if it sometimes seems like the sheriff has served an eviction notice on everyone who lives in your imagination, hang around. Chances are they have only stepped out for a while and will be back soon, talking and doing things that will surprise you.

Whatever genre we choose, we cannot allow our cells to become cages for our imaginations and intellects. We must hold both dear, and if something smolders inside us, if we have an immense respect for the wordsmiths we have read through the years and a desire to emulate them to the extent of whatever talents we might possess, then we will take the necessary steps to make the required sacrifices. It is never easy. It takes work and dedication, but by perfecting our craft, we show the world that we are more than numbers on cheap garments, that we are human beings worthy of recognition and respect. Quality can overcome the deepest prejudice, and as convict writers, we cannot afford to put before the reading public anything less than our best efforts.

We inside have already experienced rejection by society in general, and it has not broken all of us. If writing is important, we will create something unique and worthy, even if others do not endorse us as human beings or agree with our finished product. That is where our intrinsic toughness, the ability to weather a storm and stick to a planned course of action, comes into play. We refuse to quit, to lie down and accept the defeat that is expected of us. Writers, especially convict writers, are among the most durable men and women on the face of the Earth. We have no choice; we must write, and that is why when we do succeed, the recognition - the ineluctable joy of doing something few can manage makes all the work, all the sacrifices, that much sweeter. 